\title{
EVOLUÇÃO DOS MODELOS FEDERATIVOS NO CONSTITUCIONALISMO BRASILEIRO
}

Como forma de melhor visualização do quadro federativo hoje delineado pela Constituição de 1988, e de situar as transferências voluntárias no contexto do federalismo por cooperação, será feita uma breve abordagem dos textos constitucionais ao longo da história, acompanhando a evolução dos modelos federativos nacionais.

\subsection{CONSTITUIÇÃO DE 1891}

Iniciando-se pela Constituição de 1891, o texto constitucional estabeleceu, em seu artigo $1^{\circ}$, nos moldes preconizados pelo Decreto n. 1 , de 15 de novembro de $1889,{ }^{1}$ a seguinte caracterização do Estado brasileiro: "a Nação brasileira adota como forma de Governo, sob o regime representativo, a República Federativa, proclamada a 15 de novembro de 1889 , e constitui-se, por união perpétua e indissolúvel das suas antigas Províncias, em Estados Unidos do Brasil”.

O Brasil viveu um período sob a égide do chamado federalismo dualista, particularmente observado no texto constitucional de 1891, numa época em que o contexto fático conduzia à centralização do poder. $\mathrm{O}$ texto foi influenciado por uma visão mais liberal, adotando a estrutura do federalismo dualista, marcada pelo elenco de competências cometidas ao ente central (a União), reservando-se os poderes remanescentes aos Estados (art. 65), ${ }^{2}$ caracterizando-se, ainda, pela adoção

\footnotetext{
1 O decreto trazia a seguinte ementa: "Proclama provisoriamente e decreta como forma de governo da Nação Brasileira a República Federativa, e estabelece as normas pelas quais se devem reger os Estados Federais."

2 Dispõe o artigo: Art. 65. É facultado aos Estados:
} 
da teoria dos poderes implícitos da União, consoante previsto em seu art. 34, n. $33,{ }^{3}$ ao lado da preservação dos poderes autônomos dos Estados (art. 63). ${ }^{4}$ À luz desse perfil de distribuição de competências entre o ente central e os Estados, aponta Fernanda Dias Menezes de Almeida que a Constituição de 1891 foi mais fiel ao federalismo clássico, de forma dual. ${ }^{5}$

No contexto da Constituição de 1891, as antigas províncias foram transformadas em Estados, dotados de autonomia, incumbindo-lhes "prover, a expensas próprias, as necessidades de seu Governo e administração” (art. $5^{\circ}$ ). Para a consecução de suas atribuições, foi reservada aos Estados a competência para a instituição dos impostos a) sobre a exportação de mercadorias de sua própria produção, b) sobre imóveis rurais e urbanos, c) sobre transmissão de propriedade e d) sobre indústrias e profissões, bem como a instituição de taxas de selos quanto aos atos emanados de seus respectivos Governos e negócios de sua economia, e de contribuiç̧ões concernentes aos seus telégrafos e correios (art. $9^{\circ}$ ).

Não se via, no texto de 1891, o viés colaborativo do federalismo, exceto na previsão atinente à prestação de socorro aos Estados em caso de calamidade pública. A repartição de competências materiais também não se evidenciava nos moldes hoje existentes, enfraquecendo a concepção de um federalismo cooperativo no início da República.

\subsection{CONSTITUIÇÃO DE 1934}

A Constituição de 1934 foi o diploma constitucional que marcou a implantação do federalismo cooperativo no sistema constitucional brasileiro, em um contexto influenciado pela crise econômica mundial e pela necessidade de manutenção dos princípios do Estado do bem-estar social. Promulgada, então, em meio a uma crise internacional, caracterizada pela recessão econômica, redução da produção industrial e altas taxas de desemprego, teve como objetivo expresso em seu próprio

$1^{\circ}$ ) celebrar entre si ajustes e convençōes sem caráter político (art. 48, n. 16);

$2^{\circ}$ ) em geral, todo e qualquer poder ou direito, que lhes não for negado por cláusula expressa ou implicitamente contida nas cláusulas expressas da Constituição." (Grifos nossos)

3 Dispõe o artigo: Art. 34. Compete privativamente ao Congresso Nacional:

(...)

33. decretar as leis e resoluções necessarias ao exercicio dos poderes que pertencem á União.

4 Dispõe o artigo: Art. 63. Cada Estado reger-se-á pela Constituição e pelas leis que adotar respeitados os princípios constitucionais da União.

5 ALMEIDA, Fernanda Dias Menezes de, cit., p. 40. 
preâmbulo "a finalidade de "organizar um regime democrático que assegure à $\mathrm{Na}$ ção a unidade, a liberdade e justiça e o bem-estar social e econômico".

\section{Explica Wilba Lúcia Maia Bernardes:}

(...) a introdução do federalismo cooperativo no Brasil deve-se também, a uma tentativa e reivindicação dos Estados mais pobres da federação de equiparar ou de minimizar as disparidades de níveis de desenvolvimento entre as diversas unidades da federação (que acabou por fomentar o predomínio dos Estados mais ricos da federação, como São Paulo, Minas Gerais e Rio Grande do Sul na República Velha, daí a "política do café-com-leite), pois esses só conseguiriam prover suas necessidades com o apoio federal. ${ }^{6}$

A introdução do caráter cooperativo no federalismo brasileiro pela Constituição de 1934 também constituiu objeto de estudo de Marcelo Figueiredo. A respeito do assunto, o autor comentou:

Em 1934, a edição de uma nova Constituição fortaleceu os poderes federais e possibilitou o surgimento de um federalismo de caráter cooperativo, tornando as relaçôes entre a União e os Estados-membros mais próximas e coordenadas. Dessa forma, uma posição e influência preponderante da União no tratamento do interesse geral diminuiu cada vez mais o papel dos Estados. ${ }^{7}$

Em consequência, a Constituição de 1934 foi o primeiro diploma constitucional brasileiro a prever a distribuição de competências concorrentes entre a União e os Estados, ao lado das competências privativas de cada esfera. ${ }^{8}$ Fernanda Dias Menezes de Almeida salienta a influência da Constituição de Weimar, especialmente em relação à adoção da competência concorrente não-cumulativa, "em que se confere à União a fixação de normas gerais sobre certas matérias e aos Estados a

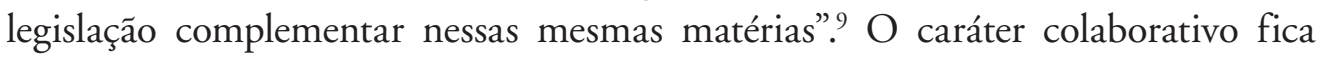
bem claro diante das seguintes disposições constitucionais:

6 BERNARDES, Wilba Lúcia Maia, cit., p. 230.

7 FIGUEIREDO, Marcelo. Direito constitucional: estudos interdisciplinares sobre federalismo, democracia e administração pública. Belo Horizonte: Fórum, 2012, p. 228.

8 Dispóe o artigo: Art. $5^{\circ}, \$ 3^{\circ}$ A competência federal para legislar sobre as matérias dos números XIV e XIX, letras $c$ e $i$, in fine, e sobre registros públicos, desapropriaçóes, arbitragem comercial, juntas comerciais e respectivos processos; requisiçóes civis e militares, radiocomunicação, emigração, imigração e caixas econômicas; riquezas do subsolo, mineração, metalurgia, águas, energia hidrelétrica, florestas, caça e pesca, e a sua exploração não exclui a legislação estadual supletiva ou complementar sobre as mesmas matérias. As leis estaduais, nestes casos, poderão, atendendo às peculiaridades locais, suprir as lacunas ou deficiências da legislação federal, sem dispensar as exigências desta.

9 ALMEIDA, Fernanda Dias Menezes de, cit., p. 40. 
Art. 9० É facultado á União e aos Estados celebrar acôrdos para a melhor coordenação e desenvolvimento dos respectivos serviços, e, especialmente, para a uniformização de leis, regras ou praticas, arrecadação de impostos, prevenção e repressão da criminalidade e permuta de informacções.

Art. 10. Compete concorrentemente á União e aos Estados:

I - velar na guarda da Constituição e das leis;

II - cuidar da saúde e assistencia publicas;

III - proteger as bellezas naturaes e os monumentos de valor histórico ou artistico, podendo impedir a evasão de obras de arte;

IV - promover a colonização;

$\mathrm{V}$ - fiscalizar a applicação das leis sociaes;

VI - diffundir a instrucção publica em todos os seus graus;

VII - crear outros impostos, além dos que lhes são attribuidos privativamente.

Paragrapho único. A arrecadação dos impostos a que se refere o n. VII será feita pelos Estados, que entregarão, dentro do primeiro trimestre do exercicio seguinte, trinta por cento á União, e vinte por cento aos Municipios de onde tenham provindo. Se o Estado faltar ao pagamento das cotas devidas á União ou aos Municipios, o lançamento e a arrecadação passarão a ser feitos pelo Governo Federal, que attribuirá, nesse caso, trinta por cento ao Estado e vinte por cento aos Municipios.

Além das competências concorrentes, o caráter colaborativo também sobressai de alguns dispositivos que disciplinam a competência privativa dos entes federados, como a previsão da possibilidade de celebração de acordos com vistas à execução de atribuições da União:

Art. 50 Compete privativamente à União:

$\$ 1^{\circ}$ Os atos, decisões e serviços federais serão executados em todo o País por funcionários da União, ou, em casos especiais, pelos dos Estados, mediante acordo com os respectivos Governos.

Art. $7^{\text {o }}$ Compete privativamente aos Estados:

(...)

Parágrafo único. Podem os Estados, mediante acordo com o Governo da União, incumbir funcionários federais de executar leis e serviços estaduais e atos ou decisões das suas autoridades.

No tocante à matéria financeira e tributária, o texto constitucional estabeleceu a divisão de arrecadação do produto de impostos de competência residual (art. 10, parágrafo único),${ }^{10}$ tendo sido prevista, ainda, a transferência facultativa de impostos

10 Dispõe o artigo: Art. 10. Compete concorrentemente à União e aos Estados: 
estaduais para os Municípios (art. 13, $\$ 2^{\circ}$ ), ${ }^{11}$ assim como o auxílio compulsório à região Nordeste, por meio da destinação de no mínimo $4 \%$ da receita de impostos federais a obras e serviços contra a seca (art. 177, caput e $\left.\$ 3^{\circ}\right) .{ }^{12}$

Assim, a introdução do federalismo cooperativo se fez com a previsão de um rol de competências concorrentes, conferindo-se à União competência para a edição de normas de caráter geral, restando aos Estados a possibilidade de suplementar a legislação federal, de acordo com suas especificidades. ${ }^{13}$ Além disso, a Constituição

(..)

VII - criar outros impostos, além dos que lhes são atribuídos privativamente.

Parágrafo único. A arrecadação dos impostos a que se refere o número VII será feita pelos Estados, que entregarão, dentro do primeiro trimestre do exercício seguinte, trinta por cento à União, e vinte por cento aos Municípios de onde tenham provindo. Se o Estado faltar ao pagamento das cotas devidas à União ou aos Municípios, o lançamento e a arrecadação passarão a ser feitos pelo Governo federal, que atribuirá, nesse caso, trinta por cento ao Estado e vinte por cento aos Municípios.

11 Dispōe o artigo: Art. 13. (...)

$\$ 2^{\circ}$ Além daqueles de que participam, ex vi dos arts. $8^{\circ}, \$ 2^{\circ}$, e 10 , parágrafo único, e dos que lhes forem transferidos pelo Estado, pertencem aos Municípios:

I - o imposto de licenças;

II - os impostos predial e territorial urbanos, cobrado o primeiro sob a forma de décima ou de cédula de renda;

III - o imposto sobre diversões públicas;

IV - o imposto cedular sobre a renda de imóveis rurais;

$\mathrm{V}$ - as taxas sobre serviços municipais.

12 Dispõe o artigo: Art. 177. A defesa contra os efeitos das secas nos Estados do Norte obedecerá a um plano sistemático e será permanente, ficando a cargo da União, que dependerá, com as obras e os serviços de assistência, quantia nunca inferior a quatro por cento da sua receita tributária sem aplicação especial.

$\$ 1^{\circ}$ Dessa percentagem, três quartas partes serão gastas em obras normais do plano estabelecido, e o restante será depositado em caixa especial, a fim de serem socorridos, nos termos do art. $7^{\circ}, \mathrm{n}$. II, as populaçôes atingidas pela calamidade.

$\$ 2^{\circ}$ O Poder Executivo mandará ao Poder Legislativo, no primeiro semestre de cada ano, a relação pormenorizada dos trabalhos terminados, e em andamento, das quantias despendidas com material e pessoal no exercício anterior, e das necessárias para a continuação das obras.

$\$ 3^{\circ}$ Os Estados e Municípios compreendidos na área assolada pelas secas empregarão quatro por cento da sua receita tributária, sem aplicação especial, na assistência econômica à população respectiva.

$\$ 4^{\circ}$ Decorridos dez anos, será por lei ordinária revista a percentagem acima estipulada.

13 O caráter concorrente da legislação vem assim definido pelo $₫ 3^{\circ}$ do art. $5^{\circ}$ da Constituição de 1934: $\$ 3^{\circ}$ A competência federal para legislar sobre as matérias dos números XIV e XIX, letras $c$ e $i$, in fine, e sobre registros públicos, desapropriações, arbitragem comercial, juntas comerciais e respectivos processos; requisições civis e militares, radiocomunicação, emigração, imigração e caixas econômicas; riquezas do subsolo, mineração, metalurgia, águas, energia 
previu competências não legislativas concorrentes, assim como a atuação concorrente da União e dos Estados para a instituição de impostos. ${ }^{14}$ Foi justamente esse campo das competências concorrentes não legislativas entre União e Estados que se tornou importante seara de atuação dos entes federados no contexto do federalismo cooperativo posteriormente, como se verá adiante.

\subsection{CONSTITUIÇÃO DE 1937}

A Carta de 1937, por sua vez, apresentou forte caráter centralizador e restringiu o espectro de matérias passíveis de serem tratadas de forma concorrente pela União e pelos Estados, atenuando, dessa forma, o caráter colaborativo impingido pela Carta de $1934 .{ }^{15}$ Não obstante tenha mantido a autonomia dos Estados, a Constituição ainda previu a possibilidade de transformação dos mesmos em

hidrelétrica, florestas, caça e pesca, e a sua exploração não exclui a legislação estadual supletiva ou complementar sobre as mesmas matérias. As leis estaduais, nestes casos, poderão, atendendo às peculiaridades locais, suprir as lacunas ou deficiências da legislação federal, sem dispensar as exigências desta." Quanto a esse aspecto, no entanto, pontua Wilba Lúcia Maia Bernardes que a "legislação supletiva ou complementar antes de se afigurar como coordenação tem o viés de subordinação com uma centralização de todo excessiva por parte do governo central" (cit., p. 230).

14 Dispóe o artigo: Art. 10. Compete concorrentemente à União e aos Estados:

(...)

VII - criar outros impostos, além dos que lhes são atribuídos privativamente.”

15 Dispõe o artigo: Art. 18. Independentemente de autorização, os Estados podem legislar, no caso de haver lei federal sobre a matéria, para suprir-lhes as deficiências ou atender às peculiaridades locais, desde que não dispensem ou diminuam as exigências da lei federal, ou, em não havendo lei federal e até que esta regule, sobre os seguintes assuntos:

a) riquezas do subsolo, mineração, metalurgia, águas, energia hidrelétrica, florestas, caça e pesca e sua exploração;

b) radiocomunicação; regime de eletricidade, salvo o disposto no n. XV do art. 16;

c) assistência pública, obras de higiene popular, casas de saúde, clínicas, estações de clima e fontes medicinais;

d) organizaçôes públicas, com o fim de conciliação extrajudiciária dos litígios ou sua decisão arbitral;

e) medidas de polícia para proteção das plantas e dos rebanhos contra as moléstias ou agentes nocivos;

f) crédito agrícola, incluídas as cooperativas entre agricultores;

g) processo judicial ou extrajudicial.

Parágrafo único. Tanto nos casos deste artigo, como no do artigo anterior, desde que o Poder Legislativo federal ou o Presidente da República haja expedido lei ou regulamento sobre a matéria, a lei estadual ter-se-á por derrogada nas partes em que for incompatível com a lei ou regulamento federal. 
territórios caso não fossem suficientemente autônomos na manutenção de seus serviços (art. $\left.8^{\circ}\right) .{ }^{16}$ Nessa medida, ao menos formalmente, foram mantidos os princípios do federalismo, basicamente centrado na autonomia dos entes federados e na distribuição de competências, embora na prática a centralização do poder tenha se tornado mais evidenciada.

Fernanda Dias Menezes de Almeida aponta também "uma inovação em relação ao direito anterior: a possibilidade de se delegar aos Estados, por lei federal, a faculdade de legislarem sobre matérias de competência privativa da União, para regulá-las ou suprirem lacunas, em questóes de interesse predominante de um ou alguns Estados". ${ }^{17}$ A esse propósito, dispunha o artigo 17 do texto constitucional:

Art. 17. Nas matérias de competência exclusiva da União, a lei poderá delegar aos Estados a faculdade de legislar, seja para regular a matéria, seja para suprir as lacunas da legislação federal, quando se trate de questão que interesse, de maneira predominante, a um ou alguns Estados. Nesse caso, a lei votada pela Assembléia estadual só entrará em vigor mediante aprovação do Governo federal.

Manteve, no entanto, as disposições que permitiam a execução estadual de serviços de competência federal (art. 19), ${ }^{18}$ assim como a possibilidade de delegação a funcionários da União para a execução de leis (art. 22). ${ }^{19}$ No campo financeiro, foi suprimida a destinação de parte das receitas de impostos federais ao Nordeste, assim como a transferência das receitas auferidas no exercício da competência residual.

\subsection{CONSTITUIÇÃO DE 1946}

A Constituição de 1946 se notabilizou pela tentativa de retomada do caráter cooperativo da Constituição de 1934, conforme aponta Fernanda Dias Menezes de Almeida: "Em 1946 manteve-se a técnica que vinha de 1934: poderes enumerados

16 Dispõe o artigo: Art. 80 A cada Estado caberá organizar os serviços do seu peculiar interesse e custeal-os com seus proprios recursos.

Paragrapho unico. O Estado que, por tres annos consecutivos, não arrecadar receita sufficiente á manutenção dos seus serviços, será transformado em territorio até o restabelecimento de sua capacidade financeira.

17 ALMEIDA, Fernanda Dias Menezes de, cit., p. 41.

18 Dispõe o artigo: Art. 19. A lei pode estabelecer que serviços de competência federal sejam de execução estadual; neste caso ao Poder Executivo federal caberá expedir regulamentos e instruções que os Estados devam observar na execução dos serviços.

19 Dispõe o artigo: Art. 22. Mediante acordo com o Governo federal, poderão os Estados delegar a funcionários da União a competência para a execução, de leis, serviços, atos ou decisões do, seu governo. 
da União (o art. $5^{\circ}$ define suas competências legislativas e de execução), poderes remanescentes dos Estados (art. 18, $\$ 1^{\circ}$ ), poderes legislativos concorrentes cabendo aos Estados a competência supletiva e complementar (art. $6^{\circ}$ )." ${ }^{20}$

Não houve no texto constitucional de 1946 a previsão de competências concorrentes não legislativas, elemento fulcral do federalismo cooperativo, tendo sido, no entanto, mantida a autonomia dos Estados, assim como o caráter colaborativo na possibilidade de execução recíproca dos serviços da competência de uma esfera de governo pelos funcionários da outra esfera. Nesse sentido, destacamos as seguintes passagens do texto constitucional, especialmente extraídas de seu artigo 18:

Art. 18. Cada Estado se regerá pela Constituição e pelas leis que adotar, observados os princípios estabelecidos nesta Constituição.

$\$ 1^{\circ}$ Aos Estados se reservam todos os poderes que, implícita ou explicitamente, não lhes sejam vedados por esta Constituição.

$\$ 2^{\circ}$ Os Estados proverão às necessidades do seu Governo e da sua Administração, cabendo à Uniáo prestar-lhes socorro, em caso de calamidade pública.

$\$ 3^{\circ}$ Mediante acordo com a União, os Estados poderão encarregar funcionários federais da execução de leis e serviços estaduais ou de atos e decisooses das suas autoridades; e, reciprocamente, a União poderá, em matéria da sua competência, cometer a funcionários estaduais encargos análogos, provendo às necessárias despesas. (Grifo nosso)

Verifica-se que, embora mantida a autonomia, prevalecia o sincronismo nas relações entre a União e os Estados-membros. O caráter cooperativo prevalecia também no âmbito do Poder Judiciário, onde a União participava da remuneração dos membros da Magistratura estadual, consoante se extrai do artigo 124 do texto constitucional:

Art. 124. Os Estados organizarão a sua Justiça, com observância dos arts. 95 a 97 e também dos seguintes princípios:

\section{(...)}

$\$ 1^{\circ} \mathrm{A}$ União prestará a cooperação financeira que fôr necessária a assegurar aos juízes dos Estados remuneração, correspondente à relevância de suas funçōes. (Incluído pela Emenda Constitucional n. 16, de 1965)

$\$ 2^{\circ}$ A cooperação será solicitada justificadamente, pelo Govêrno do Estado, através de qualquer dos seus podêres, e não será deferida se os juízes da entrância mais graduada estiverem percebendo vencimentos iguais ou superiores aos do juiz federal que nêle tiver exercício. (Incluído pela Emenda Constitucional n. 16, de 1965)

20 ALMEIDA, Fernanda Dias Menezes de, cit., p. 42. 
$\$ 3^{\circ}$ A vantagem decorrente do subsídio federal não se incorporará aos vencimentos dos magistrados para o efeito do artigo 95, III, nem excederá um quarto dos vencimentos que os magistrados estiverem percebendo na ocasião. (Incluído pela Emenda Constitucional n. 16, de 1965). ${ }^{21}$

Em continuidade, o caráter colaborativo apareceu de forma expressa também no artigo 153, que trata do aproveitamento dos recursos minerais, especialmente acerca dos estudos relacionados às águas termominerais, consoante $₫ 4^{\circ}$ :

Art. 153. O aproveitamento dos recursos minerais e de energia hidráulica depende de autorização ou concessão federal na forma da lei.

(...)

\ $4^{\circ}$ A União, nos casos de interesse geral indicados em lei, auxiliará os Estados nos estudos referentes às águas termominerais de aplicação medicinal e no aparelhamento das estâncias destinadas ao uso delas. (Grifo nosso)

Por fim, pela primeira vez em um texto constitucional brasileiro, surgiu previsão expressa da atuação cooperativa da União junto ao sistema de ensino, que se intensificou nos textos das ulteriores constituições:

Art. 170. A União organizará o sistema federal de ensino e o dos Territórios.

Parágrafo único. O sistema federal de ensino terá caráter supletivo, estendendo-se a todo o País nos estritos limites das deficiências locais.

Art. 171. Os Estados e o Distrito Federal organizarão os seus sistemas de ensino.

Parágrafo único. Para o desenvolvimento desses sistemas a União cooperará com auxílio pecuniário, o qual, em relação ao ensino primário, provirá do respectivo Fundo Nacional. (Grifo nosso)

No aspecto financeiro, foram retomadas as previsões de transferências intergovernamentais abandonadas pelo texto de 1937. O texto constitucional fez constar a previsão de distribuição do produto da arrecadação do imposto único sobre operações relativas ao carvão mineral e aos combustíveis e lubrificantes líquidos, na ordem de 65\% aos Estados, Distrito Federal e Municípios, segundo critérios estabelecidos em lei federal (art. 15, $\$ 2^{\circ}$ ). ${ }^{22}$ Foi prevista também a transferência de

21 Observe-se, no entanto, que a previsão mencionada não constava do texto originário da Constituição de 1946, tendo sido inserida somente com a Emenda Constitucional n. 16, de 1965, elaborada sob influência do regime autoritário militar.

22 Dispõe o artigo: Art. 15. Compete à União decretar impostos sobre:

(...)

III produção, comércio, distribuição e consumo, e bem assim importação e exportação de lubrificantes e de combustíveis líquidos ou gasosos de qualquer origem ou natureza, estendendo-se esse regime, no que for aplicável, aos minerais do País e à energia elétrica; 
$15 \%$ da receita do imposto sobre a renda aos Municípios (art. 15, $\$ 5^{\circ}$ ), ${ }^{23}$ assim como $10 \%$ do imposto sobre o consumo, além do excesso de arrecadação estadual (art. 15, $\$ 4^{\circ}$ ), ${ }^{24}$ consistente na transferência de 30\% do excedente resultante da diferença entre a arrecadação pelos Estados de impostos em Município diverso da capital e o total das receitas locais de qualquer natureza (art. 20). ${ }^{25}$ Convém mencionar ainda o retorno da previsão da transferência de 3\% da receita federal ao Nordeste (art. 198), ${ }^{26}$ acrescida da previsão de destinação de 3\% à Amazônia (art. 199), ${ }^{27}$ e 1\% para a região do Rio São Francisco, com o objetivo de desenvolvimento

(...)

$\$ 2^{\circ}$ A tributação de que trata o $\mathrm{n}$. III terá a forma de imposto único, que incidirá sobre cada espécie de produto. Da renda resultante, sessenta por cento no mínimo serão entregues aos Estados, ao Distrito Federal e aos Municípios, proporcionalmente à sua superfície, população, consumo e produção, nos termos e para os fins estabelecidos em lei federal.

23 Dispõe o artigo: Art. 15. Compete à União decretar impostos sobre:

(...)

IV - renda e proventos de qualquer natureza;

(...)

$\$ 5^{\circ}$ A União entregará igualmente aos Municípios 15\% (quinze por cento) do total que arrecadar do impôsto de que trata o $\mathrm{n}$. IV, feita a distribuição em partes iguais, devendo o pagamento a cada Município ser feito integralmente, de uma só vez, durante o terceiro trimestre de cada ano.

24 Dispōem o inciso II do art. 15 e o $\$ 4^{\circ}$ do mesmo dispositivo: Art. 15. Compete à União decretar impostos sobre:

(...)

II - consumo de mercadorias;

(...) $₫ 4^{\circ}$ A União entregará aos Municípios $10 \%$ (dez por cento) do total que arrecadar do impôsto de que trata o n. II, efetuada a distribuição em partes iguais, e fazendo-se o pagamento, de modo integral, de uma só vez, a cada Município, durante o quarto trimestre de cada ano.

25 Dispõe o artigo: Art. 20. Quando a arrecadação estadual de impostos, salvo a do imposto de exportação, exceder, em Município que não seja o da Capital, o total das rendas locais de qualquer natureza, o Estado dar-lhe-á anualmente trinta por cento do excesso arrecadado.

26 Dispõe o artigo: Art. 198. Na execução do plano de defesa contra os efeitos da denominada seca do Nordeste, a União dependerá, anualmente, com as obras e os serviços de assistência econômica e social, quantia nunca inferior a três por cento da sua renda tributária.

$\$ 1^{\circ}$ Um terço dessa quantia será depositado em caixa especial, destinada ao socorro das populaçôes atingidas pela calamidade, podendo essa reserva, ou parte dela, ser aplicada a juro módico, consoante as determinaçôes legais, empréstimos a agricultores e industriais estabelecidos na área abrangida pela seca.

$\$ 2^{\circ}$ Os Estados compreendidos na área da seca deverão aplicar três por cento da sua renda tributária na construção de açudes, pelo regime de cooperação, e noutros serviços necessários à assistência das suas populações.

27 Dispōe o artigo: Art. 199. Na execução do Plano de Valorização Econômica da Amazônia, a União aplicará, em caráter permanente, quantia não inferior a três por cento da sua renda tributária. 
de um plano de aproveitamento das possibilidades econômicas da região (art. 29 do Ato das Disposições Constitucionais Transitórias). ${ }^{28}$

\subsection{CONSTITUIÇÃO DE 1967}

A Constituição de 1967 foi marcada pela concentração de poderes na União, não obstante tenha sido mantida a previsão da federação e da autonomia dos entes federados. $\mathrm{O}$ artigo $8^{\circ}$ do texto constitucional veiculou extensa lista de competências da União, de caráter material e legislativo. ${ }^{29}$

28 Dispõe o artigo: Art. 29. O Governo federal fica obrigado, dentro do prazo de vinte anos, a contar da data da promulgação desta Constituição, a traçar e executar um plano de aproveitamento total das possibilidades econômicas do rio São Francisco e seus afluentes, no qual aplicará, anualmente, quantia não inferior a um por cento de suas rendas tributárias.

29 Dispõe o artigo: Art. $8^{\circ}$ Compete à União:

I - manter relaçôes com Estados estrangeiros e com eles celebrar tratados e convençôes; participar de organizaçóes internacionais;

II - declarar guerra e fazer a paz;

III - decretar o estado de sitio;

IV - organizar as forças armadas; planejar e garantir a segurança nacional;

$\mathrm{V}$ - permitir, nos casos previstos em lei complementar, que forças estrangeiras transitem pelo território nacional ou nele permaneçam. temporariamente;

VI - autorizar e fiscalizar a produção e o comércio de material bélico;

VII - organizar e manter a policia federal com a finalidade de prover:

a) os serviços de política marítima, aérea e de fronteiras;

b) a repressão ao tráfico de entorpecentes;

c) a apuração de infraçôes penais contra a segurança nacional, a ordem política e social, ou em detrimento de bens, serviços e interesses da União, assim como de outras infrações cuja prática tenha repercussão interestadual e exija repressão uniforme, segundo se dispuser em lei;

d) a censura de diversôes públicas;

VIII - emitir moedas;

IX - fiscalizar as operações de crédito, capitalização e de seguros;

$\mathrm{X}$ - estabelecer o plano nacional de viação;

XI - manter o serviço postal e o Correio Aéreo Nacional;

XII - organizar a defesa permanente contra as calamidades públicas, especialmente a seca e as inundações;

XIII - estabelecer e executar planos regionais de desenvolvimento;

XIV - estabelecer planos nacionais de educação e de saúde;

$\mathrm{XV}$ - explorar, diretamente ou mediante autorização ou concessão:

a) os serviços de telecomunicaçóes;

b) os serviços e instalações de energia elétrica de qualquer origem ou natureza;

c) a navegação aérea;

d) as vias de transporte entre portos marítimos e fronteiras nacionais ou que transponham os limites de um Estado, ou Território;

XVI - conceder anistia,

XVII - legislar sobre: 
O texto constitucional de 1967 manteve o modelo de repartição de competências delineado pela Constituição de 1946. Assim, conforme aponta Fernanda Dias Menezes de Almeida:

(...) as competências de execução e de legislação da União apareceram enumeradas no artigo $8^{\circ}$. Para os Estados ficaram os poderes remanescentes (art. 13, $\left.\$ 1^{\circ}\right)^{30}$ e a legislação supletiva sobre determinadas matérias incluídas na competência legislativa da União (art. $8^{\circ}, \$ 2^{\circ}$, do texto primitivo; art. $8^{\circ}$, parágrafo único, do texto emendado em 69). ${ }^{31}$ Mediante convênios, União, Estados e Municípios poderiam acertar a
a) a execução da Constituição e dos serviços federais;
b) direito civil, comercial, penal, processual, eleitoral, agrário, aéreo, marítimo e do trabalho;
c) normas gerais de direito financeiro; de seguro e previdência social; de defesa e proteção da saúde; de regime penitenciário;
d) produção e consumo;
e) registros públicos e juntas comerciais;
f) desapropriação;
g) requisições civis e militares em tempo de guerra;
h) jazidas, minas e outros recursos minerais; metalurgia; florestas, caça e pesca;
i) águas, energia elétrica e telecomunicações;
j) sistema monetário e de medidas; título e garantia dos metais;
l) política de crédito, câmbio, comércio exterior e interestadual; transferência de valores para fora do País;
m) regime dos portos e da navegação de cabotagem, fluvial e lacustre;
n) tráfego e trânsito nas vias terrestres;
o) nacionalidade, cidadania e naturalização; incorporação dos silvícolas à comunhão nacional;
p) emigração e imigração; entrada, extradição e expulsão de estrangeiros;
$q$ ) diretrizes e bases da educação nacional; normas gerais sobre desportos;
r) condições de capacidade para o exercício das profissões liberais e técnico-científicas;
s) uso dos símbolos nacionais;
t) organização administrativa e judiciária do Distrito Federal e dos Territórios;
u) sistemas estatístico e cartográfico nacionais;
v) organização, efetivos, instrução, justiça e garantias das policias militares e condiçôes gerais de sua convocação, inclusive mobilização.

30 Dispõe o artigo: Art. 13. Os Estados se organizam e se regem pelas Constituições e pelas leis que adotarem, respeitados, dentre outros princípios estabelecidos nesta Constituição, os seguintes:

(...)

$\$ 1^{\circ}$ Cabem aos Estados todos os poderes não conferidos por esta Constituição à União ou aos Municípios.

31 Dispõe o artigo: Art. $\mathbf{8}^{\circ}(. .$.

$\$ 2^{\circ}$ A competência da União não exclui a dos Estados para legislar supletivamente sobre as matérias das letras $c, d, e, n, q$ e $v$ do item XVII, respeitada a lei federal. 
execução de suas leis, serviços e decisões por intermédio de funcionários federais, estaduais e municipais $\left(\operatorname{art} .8^{\circ}, \$ 1^{\circ} \text { e art. } 13, \$ 3^{\circ}\right)^{32-33}$

Ao lado do centralismo, destaca-se a previsão atinente ao repasse de recursos aos Estados, Distrito Federal e Municípios, por meio da introdução, no texto constitucional, do Fundo de Participação dos Estados e do Fundo de Participação dos Municípios, criados pela Emenda Constitucional n. 18, de 1965, e posteriormente alterados pelo Ato Complementar n. 40, de $1968 .^{34}$

32 Dispóem o $\$ 1^{\circ}$ do art. $8^{\circ}$ e o $\$ 3^{\circ}$ do art. 13: Art. $8^{\circ}(\ldots)$

$\$ 1^{\circ}$ A União poderá celebrar convênios com os Estados para a execução, por funcionários estaduais, de suas leis, serviços ou decisões.

(...) Art. 13. (...)

$\$ 3^{\circ}$ Para a execução, por funcionários federais ou municipais, de suas leis, serviços ou decisões, os Estados poderão celebrar convênios com a União ou os Municípios.

33 ALMEIDA, Fernanda Dias Menezes de, cit., p. 43.

34 Dispõe o artigo: Art. 26. Do produto da arrecadação dos impostos a que se refere o art. 22, ns. IV e V, a União distribuirá doze por cento na forma seguinte:

I - cinco por cento ao Fundo de Participação dos Estados e do Distrito Federal; (Incluído pelo Ato Complementar n. 40, de 1968);

II - cinco por cenho ao Fundo de Participação dos Municípios; (Incluído pelo Ato Complementar n. 40, de 1968);

III - dois por cento ao Fundo Especial a que se refere o $\$ 3^{\circ}$ deste artigo. (Incluído pelo Ato Complementar n. 40, de 1968);

$\$ 1^{\circ} \mathrm{A}$ aplicação dos Fundos previstos nos incisos I e II deste artigo será regulada por lei federal, que cometerá ao Tribunal de Contas da União o cálculo das cotas estaduais e municipais, condicionando-se a entrega das cotas: (Redação dada pelo Ato Complementar n. 40, de 1968); a) à aprovação de programas de aplicação elaborados pelos Estados, Distrito Federal e Municípios, com base nas diretrizes e prioridades estabelecidas, pelo Poder Executivo federal; (Incluída pelo Ato Complementar n. 40, de 1968);

b) à vinculação de recursos próprios, pelos Estados, Distrito Federal e Municípios, para execução dos programas referidos na alínea $a$; (Incluída pelo Ato Complementar n. 40, de 1968);

c) à transferência efetiva para os Estados, Distrito Federal e Municípios, de encargos executivos da União; (Incluída pelo Ato Complementar n. 40, de 1968);

d) ao recolhimento dos impostos federais arrecadados pelos Estados, Distrito Federal e Municípios, e à liquidação das dívidas dessas entidades, ou de seus órgãos da Administração Indireta, para com a União, inclusiva em decorrência de prestação de garantia. (Incluída pelo Ato Complementar n. 40, de 1968);

$\$ 2^{\circ}$ Para efeito do cálculo da percentagem destinada aos Fundos de Participação, exclui-se a parcela do imposto de renda e proventos de qualquer natureza que, nos termos dos arts. $24, \mathbb{\$}$ $1^{\circ}$ e $25, \$ 1^{\circ}$, letra $a$, pertencente, aos Estados e Municípios. (Redação dada pelo Ato Complementar n. 40, de 1968);

$\$ 3^{\circ} \mathrm{O}$ Fundo Especial terá sua destinação regulada em lei tendo em vista a aplicação do sistema tributário estabelecido nesta Constituição.

Dispõe o artigo: Art. 27. Sem prejuízo do disposto no art. 25, os Estados e Municípios, que celebrarem com a União convênios destinados a assegurar a coordenação dos respectivos pro- 
No âmbito da repartição de receitas tributárias, a Carta de 1967 acabou dispondo de forma mais minuciosa acerca da participação dos Estados e Municípios na receita de impostos da União, o que até então não era verificado nos textos constitucionais. O artigo 28 previu a distribuição de $40 \%$ do produto de arrecadação do imposto sobre a produção, importação, circulação, distribuição ou consumo de lubrificantes e combustíveis líquidos e gasosos (art. 22, inciso VIII), 60\% sobre a arrecadação incidente sobre a produção, importação, distribuição ou consumo de energia elétrica (art. 22, inciso IX), e 90\% do produto do imposto sobre a extração, circulação, distribuição ou consumo de minerais do País (art. 22, inciso X) aos Estados, Distrito Federal e Municípios. ${ }^{35}$

Além disso, $20 \%$ da arrecadação do imposto incidente sobre operações relativas à circulação de mercadorias realizadas por produtores, industriais e comerciantes, de competência dos Estados, deveria ser repassado aos Municípios (art. 24, \$7o). ${ }^{36}$

Em síntese, Fernanda Dias Menezes de Almeida afirma que "o esquema de repartição de competências adotado em 1967 remontou a modelos que, como visto, não se tinham revelado eficientes na contenção da tentativa centrípeta verificada nas Federações de modo geral". ${ }^{37}$

gramas de investimento e administração tributária, poderão participar de até dez por cento na arrecadação efetuada, nos respectivos territórios, proveniente dos impostos referidos no art. 22, ns. IV e V, excluído o incidente sobre fumo e bebidas.

35 Dispõe o artigo: Art. 28. A União distribuirá aos Estados, Distrito Federal e Municípios:

I - quarenta por cento da arrecadação do imposto a que se refere o art. 22, n. VIII;

II - sessenta por cento da arrecadação do imposto a que se refere o art. 22, n. IX;

III - noventa por cento da arrecadação do imposto a que se refere o art. 22, n. X.

Parágrafo único. A distribuição será feita nos termos da lei federal, que poderá dispor sobre a forma e os fins de aplicação dos recursos distribuídos, obedecido o seguinte critério:

a) nos casos dos itens I e II, proporcional à superfície, população, produção e consumo, adicionando-se, quando couber, no tocante ao n. II, cota compensatória da área inundada pelos reservatórios;

b) no caso do item III, proporcional à produção.

36 Dispõe o artigo: Art. 24. Compete aos Estados e ao Distrito Federal decretar impostos sobre: (...)

II - operaçôes relativas à circulação de mercadorias, realizadas por produtores, industriais e comerciantes. (Redação dada pelo Ato Complementar n. 40, de 1968);

(...)

$\$ 7^{\circ}$ Do produto da arrecadação do imposto a que se refere o item II, oitenta por cento constituirão receita dos Estados e vinte por cento, dos Municípios. As parcelas pertencentes aos Municípios serão creditadas em contas especiais, abertas em estabelecimentos oficiais de crédito, na forma e nos prazos fixados em lei federal.

37 ALMEIDA, Fernanda Dias Menezes de, cit., p. 43. 


\subsection{CONSTITUIÇÃO DE 1988}

A Constituição de 1988 caracteriza-se pela grande complexidade e pelo alto nível de detalhamento das relações federativas nele estabelecidas. Conforme pontua Fernanda Dias Menezes de Almeida, o modelo adotado pelo texto constitucional de 1988 resultou da combinação de diversos modelos testados na prática federativa:

Estruturou-se, com efeito, um sistema complexo em que convivem competências privativas, repartidas horizontalmente, com competências concorrentes, repartidas verticalmente, abrindo-se espaço também para a participação das ordens parciais na esfera de competências próprias da ordem central, mediante delegação. ${ }^{38}$

No âmbito das competências privativas, o texto constitucional de 1988 fez constar, em seus artigos 21 e 22, as competências privativas da União, administrativas e legislativas. As competências dos Estados, de caráter eminentemente residual, foram previstas pelo artigo 25 , e as competências municipais, no artigo 30 . No tocante às competências administrativas, verifica-se, no entanto, a atribuição de competências mais afetas à realidade local para a União, como as competências privativas para "planejar e promover a defesa permanente contra as calamidades públicas, especialmente as secas e as inundaçōes" (art. 21, inciso XVIII) e "organizar, manter e executar a inspeção do trabalho" (art. 21, inciso XXIV), contrariando, em tese, os desígnios do federalismo.

Também foram previstas competências comuns a todos os entes, de natureza não legislativa (artigo 23), e competências concorrentes legislativas (artigo 24). Em relação às últimas, os parágrafos do artigo 24 especificam o âmbito de atuação de cada esfera, cumprindo à União a fixação de normas gerais e aos Estados a competência para suplementar a legislação federal, além da possibilidade de disciplinar inteiramente a matéria, na ausência de lei federal. ${ }^{39}$ Embora não figurem expressamente no rol dos legitimados para o exercício da competência concorrente, é reconhecida aos Municípios a competência não apenas para legislar sobre assuntos de interesse local (art. 30, inciso I), mas também para suplementar a legislação federal e a estadual no que couber (art. 30, inciso II).

38 ALMEIDA, Fernanda Dias Menezes de, cit., p. 58.

39 Dispõe o artigo: Art. 24. (...)

$\$ 1^{\circ}$ No âmbito da legislação concorrente, a competência da União limitar-se-á a estabelecer normas gerais.

$\$ 2^{\circ}$ A competência da União para legislar sobre normas gerais não exclui a competência suplementar dos Estados.

$\$ 3^{\circ}$ Inexistindo lei federal sobre normas gerais, os Estados exercerão a competência legislativa plena, para atender a suas peculiaridades.

$\$ 4^{\circ}$ A superveniência de lei federal sobre normas gerais suspende a eficácia da lei estadual, no que lhe for contrário. 
Fernanda Dias Menezes de Almeida ressalta o foco descentralizador da Constituição, tanto em razão da repartição de competências concorrentes, como também da fixação das competências comuns, qualificadas pela autora como "descentralização dos encargos". Em suas palavras:

Parece-nos, efetivamente, que a utilização das competências concorrentes, como idealizada, atende aos desígnios de se chegar a maior descentralização, sem prejuízo da direção uniforme que se deva imprimir a certas matérias.

Numa palavra, o caminho que se preferiu é potencialmente hábil a ensejar um federalismo de equilíbrio, que depende, embora, como não se desconhece, também de outras providências.

Abrir aos Estados uma esfera de competências legislativas concorrentes, em que lhes é facultado, por direito próprio, e dentro dos limites traçados pela Constituição, disciplinar uma série de matérias que antes escapavam de sua órbita de atuação legiferante, significa, por certo, ampliar-lhes os horizontes e incentivar-lhes a criatividade.

O mesmo se diga em relação à descentralização de encargos mediante o estabelecimento de uma área de competências comuns, em que da cooperação de todos os integrantes da Federação é que deverá resultar o atendimento das metas objetivadas. ${ }^{40}$

Observa-se também que o texto constitucional conferiu papel de destaque à União no planejamento nacional e regional (art. 21, inciso IX). ${ }^{41}$ Contudo, não obstante a importância ostentada pela atividade administrativa planejada, a competência, na forma como disposta, acaba por revelar uma incongruência em relação à autonomia dos entes subnacionais. Nesse aspecto, também se manifesta Fernanda Dias Menezes de Almeida:

Considerando, porém, que o planejamento é informado pelos princípios da "unidade por integração" e da "globalidade", coloca-se desde logo a dificuldade de sua conciliação com o princípio da autonomia das unidades federadas, da conciliação do processo de planejamento, que pressupõe centralização das decisões políticas, com a estrutura, descentralizadora por definição, do modelo federativo.

Como pondera JOSÉ ALFREDO DE OLIVEIRA BARACHO (1982:243), o planejamento pode levar a confrontos com o federalismo se utilizar processos de centralização autocrática, o que não é, no entanto, inevitável, já que também pode utilizar medidas de coordenação compatíveis com qualquer das formas federais existentes. E lembra que a "planificação não é contrária aos princípios constitucionais de governo

40 ALMEIDA, Fernanda Dias Menezes de, cit., p. 61. Grifo nosso.

41 Dispõe o artigo: Art. 21. Compete à União:

(...)

IX elaborar e executar planos nacionais e regionais de ordenação do território e de desenvolvimento econômico e social. 
democrático, desde que sobre a mesma existam processos de controle legislativo, administrativo e jurisdicional". ${ }^{2}$

Em continuidade, assevera:

Nessa perspectiva, a crítica maior que cabe fazer à Constituição vigente não se volta tanto para a ênfase que se continuou a dar ao planejamento nacional e regional, a cargo da União. É certo que, sem chegar ao extremo da antiga Constituição, que colocava inclusive entre as causas ensejadoras de intervenção federal nos Estados a adoção de medidas ou a execução de planos econômicos que contrariassem as diretrizes estabelecidas em lei federal, a Constituição de 1988 ainda reserva destacado papel à União em relação ao planejamento. $\mathrm{Na}$ verdade, até amplia significativamente sua atuação nessa área ao atribuir-lhe competência em termo de planejamento urbanístico. Como já referido, incumbe hoje à União elaborar e executar planos nacionais e regionais de ordenação do território, instituir diretrizes para o desenvolvimento urbano, inclusive quanto a habitação, saneamento básico e estabelecer princípios e diretrizes para o sistema nacional de viação.

O que se lamenta, numa linha de democracia participativa, é que se tenha perdido a oportunidade de tornar necessária a audiência dos Estados e dos organismos regionais ou municipais interessados, quando da elaboração dos diversos planos nacionais e regionais. Nesse sentido constava, por exemplo, no anteprojeto da Comissão Afonso Arinos, que competia à União planejar e promover o desenvolvimento nacional, ouvidos os Estados e os órgãos interessados. ${ }^{43}$

Alexandre de Moraes reconhece que a evolução do federalismo brasileiro culminou em uma redução das competências legislativas dos Estados:

No Brasil, apesar dos diversos constituintes, desde 1891 até 1988, terem criado e mantido o modelo de Estado federal, com união indissolúvel dos entes, que possuem auto-organização, autogoverno e autoadministração, no modelo proposto pelos norte-americanos, não resta dúvidas de que houve gradual redução nas competências legislativas dos Estados-membros. ${ }^{44}$

$\mathrm{O}$ autor critica essa tendência, que seria atentatória aos ideais do federalismo: A tradição de centralização das competências legislativas na União corrobora as críticas feitas por Castro Nunes ao analisar as competências legislativas do Estado-membro, caracterizando-o como "mutilado em suas atribuiçôes, sem atenção ao regimen de poderes separados que é da essência das instituiçôes democrático-republicanas." (NUNES, José de Castro. As Constituiçôes estaduaes no Brasil. Rio de Janeiro: Leite Ribeiro, 1992, t. 1, p. 68). ${ }^{45}$

42 ALMEIDA, Fernanda Dias Menezes de, cit., p. 78.

43 ALMEIDA, Fernanda Dias Menezes de, cit., p. 79.

44 MORAES, Alexandre de, cit., p. 148.

45 MORAES, Alexandre de, cit., p. 149. 
Verifica-se, dessa forma, que o texto de 1988 acabou por veicular a descentralização de diversas atribuições aos Estados e Municípios, particularmente sob o aspecto de sua execução, mantendo, porém, sob controle do ente central a definição das políticas públicas, muitas vezes sem a aquiescência e participação dos demais entes, em prejuízo, ainda, às competências legislativas dos Estados-membros. $\mathrm{Na}$ medida em que atribuições constitucionais foram distribuídas, tornou-se mais complexa e premente a redistribuição dos recursos como forma de os entes subnacionais fazerem frente às suas novas tarefas. Nesse contexto, a Constituição conferiu maior importância às transferências intergovernamentais. 